\title{
Afet Riskleri ile İlgili Kentsel Dayanıklılık Çalışmalarının Yöntemsel Olarak İncelenmesi
}

\author{
Kiymet Uzun Yüksel ${ }^{1}$ \\ ORCID: 0000-0001-9754-7552
}

\author{
Elif L. Kutay Karaçor ${ }^{2}$ \\ ORCID: 0000-0001-9636-1406
}

Öz

Resilience kavramı, ilk kez 1618 yılında yayımlanmış bir sözlükte tanımlanmıştır. Kentsel planlama alanındaki kullanımi, ekoloji bilimiyle ilgilenen Crawford Stanley Holling'in 1973 yılında yaptığı yayınındaki tanımıyla ilişkilendirilerek literatüre girmişsir. 2000'li yıllarda afet ve risk kavramlarn ile kullanılmıştır. Kavramın afet ve risk çalışmalarında kullamılmaya başlamasının temel sebeplerinden biri afetlerin, yerel ve küresel düzeyde ekonomik zararlar vermesi ve çok fazla can kaybına yol açmasıdır. Bu çalışmada afet riskleri ve dayanıklılık ilişkisi ele alınmış ve tarihsel gelişiminden bahsedilmiştir. İkincil veri ve içerik analizi yapılarak, ulusal ve uluslararası düzeyde yapulan çalışmalar irdelenmiştir. Afet ve afet riskleriyle mücadele ederken toplumsal ve mekânsal olarak yapılan 25 farklı dayanıklılık çalışması ve yöntemlerinden, kentsel dayanıklılık çalışmalarında yaygın olarak kullanılan üç model seçilmiştir. Bu üç model; Topluluklar İçin Temel Dayanıklılık Göstergeleri (Baseline Resilience Indicators For Communities), Dayanıkl Kent Göstergeleri (Arup E Rockefeller Foundation) ve Kentler İçin Afete Dayanıklılı Puan Kartları (UNISDR The Disaster Resilience Scorecard For Cities)'dır. Seçilen bu modeller, kullanılan araçlar ve yöntem açısından farklılıklar gösterdiği için birbiriyle karşılaştırılmıştır. Yapılan çalışmanın, kentsel dayanıklılı modellerinin geliştirilmesine katkı sağlayacă̆ı düşünülmektedir.

Anahtar Kelimeler: Dayanıklılık, afet riski, afet yönetimi, dayanıklılı̆̆ın ölçülmesi, dayanıklılığın değerlendirilmesi

\footnotetext{
${ }^{1}$ Araş. Gör., Düzce Üniversitesi, Email: kiymetuzun@duzce.edu.tr

${ }^{2}$ Doç. Dr., Düzece Üniversitesi, Email: elifkaracor@duzce.edu.tr

idealkent @ C Kent Araştırmaları Dergisi (Journal of Urban Studies) 


\title{
Methodological Examination of Urban Resilience Studies Related to Disaster Risks
}

\author{
Kiymet Uzun Yüksel ${ }^{3}$ \\ ORCID: 0000-0001-9754-7552
}

\author{
Elif L. Kutay Karaçor ${ }^{4}$ \\ ORCID: 0000-0001-9636-1406
}

\begin{abstract}
Resilience was first defined in a dictionary published in 1618. Its use in urban planning literature by associating it with the definition in the 1973 publication of Crawford Stanley Holling, who is interested in the ecology. It was used with the concepts of disaster and risk in the 2000s. One of the main reasons why the concept has started to be used in disaster and riskstudies is that disasters cause loss of life and property at local and global level. In this study, the historical development of disaster risks and resilience were mentioned. By doing secondary data and content analysis, national and international studies were examined. Three models, which are widely used in urban resilience studies, have been selected from 25 different resilience studies and methods conducted socially and spatially while dealing with disaster and disaster risks. These three models are; Baseline Resilience Indicators For Communities, Arup \& Rockefeller Foundation Resilience City Index, and UNISDR The Disaster Resilience Scorecard For Cities. These selected models have been compared with each other since they differ in terms of the tools and methods used. It is thought that this study will contribute to the development of urban resilience models.
\end{abstract}

Keywords: Resilience, disaster risk, disaster management, resilience measurement, resilience assessment

\footnotetext{
${ }^{3}$ R. A., Duzce University, Email: kiymetuzun@duzce.edu.tr

${ }^{4}$ Assoc. Prof., Duzce University, Email: elifkaracor@duzce.edu.tr

idealkent @ Kent Araştırmaları Dergisi (Journal of Urban Studies) 


\section{Giriş}

İnsan nüfusu, son yüzyıl içinde daha önceki yüzyıllara nazaran katlanarak artmaktadır. Nüfusun artışına bağlı olarak doğaya olan baskı artmış, yerel ve küresel anlamda pek çok sorun ortaya çıkmıştır. Buna bağlı olarak, mevcut yerleşimlerin genişlemesi ve yeni yerleşim yerlerinin artması çevre ve insan açısından risk yaratan unsurlar olmuştur. Risk yaratan durumların en başında afetler gelmektedir. Afet, toplumun işleyişinde veya insan, fiziksel, ekonomik, çevresel etkenler gibi toplumu oluşturan yapıda, toplumun taşıma kapasitesini aşan kayıplara ve etkilere yol açan bozulmalar olarak tanımlamıştır (UNISDR, 2009, s.9). Afetlerin neden olduğu olumsuz etkileri gidermek, iyileşmek ve yeniden adapte olmak, maddi ve manevi yönden hem devletler hem de toplumlar için yıpratıcıdır. Güvenli kentler yaratma ve kentsel yaşam kalitesi çalışmaları daha da önem kazanmaktadır. Bu bağlamda, kentlerin dayanıklılığını araştırmak, afet öncesi, afet sırası ve sonrası süreçlerinde, önlem almak, müdahale etmek kentlerin yaşanabilir olması, rehabilitasyonu ve dayanıklı çevreler oluşturulması için gereklidir.

Resilience kelimesi kavramsal olarak esneklik, dayanıklılık ve dirençlilik anlamında kullanılmaktadır. Türkçedeki kullanımı çoğunlukla dirençlilik, dayanıklılık şeklindedir. Resilience kelimesi ilk olarak hukukçu olan Thomas Blount tarafından 1618 yılında tanımlanmıştır. Daha sonra 1858 yılında mühendis William J. M. Rankine çelik kirişlerin mukavemetini ve sünekliğini tanımlamak için kullanmıştır (Alexander, 2013, s.2710). Bu kavram daha sonra 1973 yılında Crawford Stanley Holling tarafından biyoloji ve ekosistem alanında yer almıştır. Dayanıklılık, bir sistem içindeki ilişkilerin sürekliliğini belirleyen ve sistemlerin duruma bağlı değişkenlerinin, değişen parametreleri absorbe etme kapasitesinin bir ölçüsü olarak tanımlanmıştır. Bu tanımda dayanıklılık sistemin özelliğidir ve buna göre neslin sürdürülmesi veya yok olması buna bağlıdır (Holling, 1973, s.14). Hukuk, mühendislik, psikoloji ve ekoloji gibi pek çok disiplince farklı amaçlar için kullanılan resilience kavramı daha sonra ekonomistler ve coğrafyacılar tarafından kullanılmaya başlanmıştır. Godshalk (2003), fiziksel sistemler ve insan toplulukları arasındaki sürdürülebilir bir bağlantı olarak tanımlamıştır. Pickett, Cadenasso ve Grove (2004, s.22), sistemin değişen koşullara göre kendini ayarlama kabiliyeti olarak da bahsetmişlerdir. Sosyal bilimlerde, kent için, tahribatı geri tepme kapasitesidir (Campanella, 2006, s.141). Çevre bilimlerinde ise sistemin kendini yeniden organize ederek, başka evrelere geçmeden değişim ve bozulmadan kurtarma kapasitesi olarak tanımlanır (Ahern, 2011, s.341). Ernstson vd (2010)'nin çevre 
ve sosyal bilimleri de kapsayan dayanıklılık tanımı, belirli dinamik bir rejimi sürdürmesi için, kentsel yönetişimin de belirsizlik ve değişimle yüzleşebildiği, dönüştürücü kapasiteyi kurması gereken bir sistemdir. Afete yönelik dayanıklılık ilk kez Timmerman (1981) tarafından tanımlanmıştır. Sistemin tehlikeleri absorbe etme ve kendini iyileştirebilme kapasitesi olarak açıklamiştır.

2000'li yıllarda özellikle afet risklerini azaltmaya yönelik uygulanan politikalarda dayanıklılık vurgusu daha fazla yapılmaktadır. Dayanıklılık kavramı, afetlerin artması ve özellikle kentlerde yıkıcı sonuçlar doğurması sebebiyle kent çalışmalarında yoğun olarak kullanılmaya başlanmıştır. Kentlerin çok katmanlı yapısı, afet risklerini hesaplamak ve afete direnci artırma konusunda tartışmalıdır. Dayanıklılığın kendi içindeki çok boyutlu yapısı karmaşa yaratmaktadır. Bu sebeple pek çok araştırmacı tarafından, bu kavramlar farklı şekillerde ele alınıp, kendi uyguladıkları ölçütleriyle çeşitli yöntemler geliştirilmiştir.

\section{Afet Riski, Dayanıklılık ve Kent İlişkisi}

Afet riski, bir tehlikenin, gelecekte belirli bir zamanda ortaya çıkması hâlinde, doğal çevreye, yerleşim yerlerine ve insanlara vereceği zarar veya hasar görebilirlikleri ile orantılı ve tahminsel olarak oluşturulan kayıpların olasılığıdır (AFAD, 2018, s.60). Afete karşı dayanıklılık, tehlikelere maruz bir sistemin, toplum veya topluluğun afetle baş edebilme, afete karşı esnek ve dayanıklı olabilme, afetlerin etkisini kısa sürede gidererek iyileştirme kapasitesi olarak tanımlanır. Başka bir ifade ile tehlikeli bir olayın etkilerini etkili bir biçimde ve zamanında tahmin etme, ön görme, uyum sağlama, önleme, azaltma, baş edebilme kapasitesi ve iyileştirme yeteneğidir (UNISDR, 2016, s.14). Kentler karmaşık yapıda olmaları nedeniyle, afetlerle baş etme konusunda afet öncesinde hazırlık yapma, afet sırasında müdahale ve sonrasında iyileşme süreçlerinde kentin tüm bileşenleriyle beraber ele alınmalıdır.

Harrison ve Williams (2016) tarafından, doğal afetlerin sıklığında gözlenen artışı dikkate almış, bunların oluşturduğu risklerin azaltılmasında, benimsenmesinde ve bu tür olaylardan kaçınmada sistem yaklaşımı gerektiği savunulmuştur. Buna göre, kentsel sistem ne tamamiyla sosyal bir sistem ne de bir altyapı sistemidir, daha çok kentte yaşayanlarla, doğal ve yapılaşmış çevreler arasındaki sayısız etkileşimin olduğu sistemler bütünüdür. Kentsel sistem çoklu mekânsal ölçeklere yayılan sosyo-ekolojik ve sosyo-teknik ağlardan oluşan, karmaşık ve uyarlanabilir çok boyutlu bir haldedir. Bu sebeple 
dayanıklılık, bu boyutlarla beraber deneyimlerle kazanılan bilgilerle de tartışlmalıdır (Meerow, Newell ve Stults, 2016, s.39).

Afet riski, dayanıklılık ve kent kavramları bir arada ele alındığında kentsel dayanıklılık kavramıyla karşılaşılmaktadır. Kentsel dayanıklılık, bir kentsel sistemin (buna bağlı sosyo-ekolojik ve sosyo-teknik ağlarının zamansal ve mekânsal ölçekler) bir sorun karşısında istenen işlevleri sürdürme veya hızlıca eski işlevine geri dönme, değişime uyum sağlama, mevcuttaki ve gelecekteki adaptasyon kapasitesini sınırlayan sistemlerden çabucak değişim gösterme olarak tanımlanır. Bu tanımda, kentsel dayanıklılık dinamik bir yapıdadır ve esnekliğe giden çeşitli yollar sunar (örneğin; devamlılık, geçiş ve dönüşüm). Bu dinamizm zamansal ölçeğin önemini kabul ederek, özel adaptasyondan ziyade genel adaptasyonu destekler niteliktedir (Meerow vd., 2016, s.39).

USIAD (2016) ile Cutter, Ash ve Emrich (2014)'e göre kent düzeyindeki dayanıklılık, toplum bazlı yaklaşımla ilişkilendirilmiştir. Sosyal süreçler, doğal ve yapılı çevreden ayrı düşünülemez (Cutter vd., 2008, s.599). Kentsel doku içerisindeki, sosyo-mekansal ayrımclık ve eşitsizlikler farklı düzeylerde, zarar görebilirlik ve dayanıklılık oluşturmaktadır. Özellikle, daha yoksul topluluklar, sosyal, ekonomik ve çevresel anlamda daha kırılgan yapıdadırlar (Hillier ve Castillo, 2013, s.4). Kent çapındaki sistem yaklaşımı, farklı alanlardaki toplulukların, zarar görebilirlik ve dayanıklılık düzeylerindeki değişimi göz ardı edebilir, fakat tam aksine, dayanıklılığın toplum odaklı yaklaşımı bu ayrışmayı ve eşitsizliği ortaya koymaktadır (Figueiredo, Honiden ve Schumann 2018, s.11).

Kent ölçeğinde dayanıklılık çalışmaları yapan Sürdürülebilirlik için Yerel Yönetimler (ICLEI) (2015), ARUP ve Rockefeller Vakfi (2015), sosyo-ekolojik yaklaşımla ele almaktadır. Kent karmaşık sosyo-ekolojik ağlarla örülmüştür ve bu da kentsel sistemleri oluşturur. "Sistem düşüncesi" kentlere "bütünsel" bir bakış açısı sunar. Sistemin birden çok unsuru arasındaki değişim ve bağlantıların dinamizmi olan kentler, bir araya getirildiklerinde tek başına bulunamayacak niteliklere sahip çeşitli unsurlar içeren uyarlanabilir, sosyo-teknik sistemlerle düşünülmelidir (Figueiredo vd., 2018, s.13).

Dayanıklılık çalışmaları, yere, bulunduğu topluma ve risk altındaki tehlikeye veya olaya göre değişkenlik göstermektedir. Her ülkenin, bölgenin ve kentin kendi potansiyeli ve değişkenleri farklıdır. Bu sebeple afet riski, dayanıklılık ve kentten bahsederken, bu kavramları yere özgü olarak incelemek gerekmektedir. 


\section{Afet Risklerini Azaltma Çalışmalarının Tarihsel Süreci}

Son 50 yılda özellikle, ekonomik ve toplumsal olarak yıkıcı olan afetlerin durumuna bakıldığında ciddi bir artı̧̧ görülmektedir. Kentleşme baskısının dünya genelinde günden güne arttığı düşünüldügüünde, risk oranlarının da o ölçüde arttğ̆ görülmektedir. İlk olarak 1976'da doğrudan afetle ilişkilendirilmemiş olmasına rağmen kentsel yerleşimlerin sürdürülebilirliği konusunun tartışıldığı Habitat I Konferansı yapılmıştır. 1970'lerin sonunda çevre sorunlarının artmasıyla beraber afetle de ilgili farkındalık oluşmaya başlamıştır. $\mathrm{Bu}$ dönemde, tehlike bazlı yaklaşımla hareket edilmektedir.

1980'lere gelindiğinde afetlerin sosyal boyutu ön plana çıkmıştır. 1979'da Birleşmiş Milletlerin Afetler için yara sarma çalışmaları yapan UNDRO toplanmıştır. Bu toplantıyla beraber, risk ve zarar görebilirlik kavramları ve yara sarma çalışmaları başlamıştır. 1987 yılında yara sarma çalışması olarak, Birleşmiş Milletler Uluslararası Risk Azaltma Ofisi 1990-2000 arası yılların “Doğal Afet Etkilerini Azaltma On Y1lı" (The International Decade for Natural Disaster Reduction) olarak ilan etmiştir. 1992 yılında ekonomiyi geliştirme ve çevreyi koruma temasıyla Rio'da Dünya Zirvesi (Earth Summit) yapılmıştır. Ayrıca 1992' de Birleşmiş Milletler İklim Değişikliği Sözleşmesi kabul edilmiştir. Afetlerle mücadelede yeni stratejilerin belirlenmesi için 1994 yılında Uluslararası Yokohama Konferansı düzenlenmiştir. 1996 yılında Habitat II konferansı düzenlenmiş ve giderek artan kentsel nüfusun yeterli konut ihtiyacı ve sürdürülebilir yaşam için gerekenler gündeme getirilmiştir.

1999 yılıyla beraber afetlerin yarattığı zararların sosyal boyutu, afet yönetimi bağlamında ele alınmıştır. Birleşmiş Milletler tarafından afetlerin etkilerinin azaltılması için Uluslararası Strateji Raporu yayınlanmıştır. 2000 yılında Bin Yıllık Kalkınma Hedefleri belirlenmiştir. Afetlerin artmasıyla beraber, etkilerini azaltmak ve hedefleri gerçekleştirmek için uluslararası ortaklarla iş birliği yapılması çağrısında bulunulmuştur.

2005 yılında Japonya'nun Kobe kentinde Birleşmiş Milletler Uluslararası Afet Risklerini Azaltma Stratejileri (UNISDR) Sekretaryası tarafindan Uluslararası Kobe Konferansi (World Conference on Disaster Reduction)'nda hazırlanan değerlendirme raporu sunulmuştur. Bununla beraber 2005-2015 arası yılları kapsayan Hyogo Çerçeve Eylem Planı (Hyogo Framework for Action - HFA) oluşturulmuş ve bu çerçevede yeni Doğal Afet Risk Azaltımı On Yılı olarak belirlenmiştir. Bununla birlikte risk temelli yönetim ve dayanıklı ulustoplum yaratılması hedeflenmiştir. 2012 yılında yine Rio'da, Rio + 20 Birleş- 
miş Milletler Sürdürülebilir Kalkınma Konferansı, küresel toplumun ekonomik ve çevresel hedeflerini uzlaştırmayı amaçlayan üçüncü konferansı düzenlenmiştir (UNISDR, 2019).

2015 yılında Hyogo Eylem Planının geçerliliğinin bitmesi üzerine, Sendai Eylem Planı 2015-2030 arası yılları kapsayacak şekilde 15 yıllık olarak yapılmıştır. Bu planla riskin yönetimsel boyutu, risklere sistem bazlı yaklaşım ve dayanıklı kent, toplum ve sistem vurgusu yapılmıştır. Afetlerin global etkilerinin bariz şekilde artması üzerine 2030 Kalkınma Hedefleri ve iklim krizinin etkilerinin hafifletilmesi için Paris Antlaşması yapılmıştır. 2016 yılında sürdürülebilir kalkınma hedeflerinin, afet ve iklim krizine karşı kentleri hazırlamanın gerekliliğinin savunulduğu Yeni Kentsel Gündem (Habitat III) konferansı yapılmıştır (Şekil 1). Daha önceleri afetlerin yönetilmesi söz konusu iken, bu gelişmelerden sonra risklerin yönetilmesi baz alınmıştır ve risk temelli sürdürülebilir bir gelişme hedefi ile ilerlenmektedir (UNISDR, 2019).

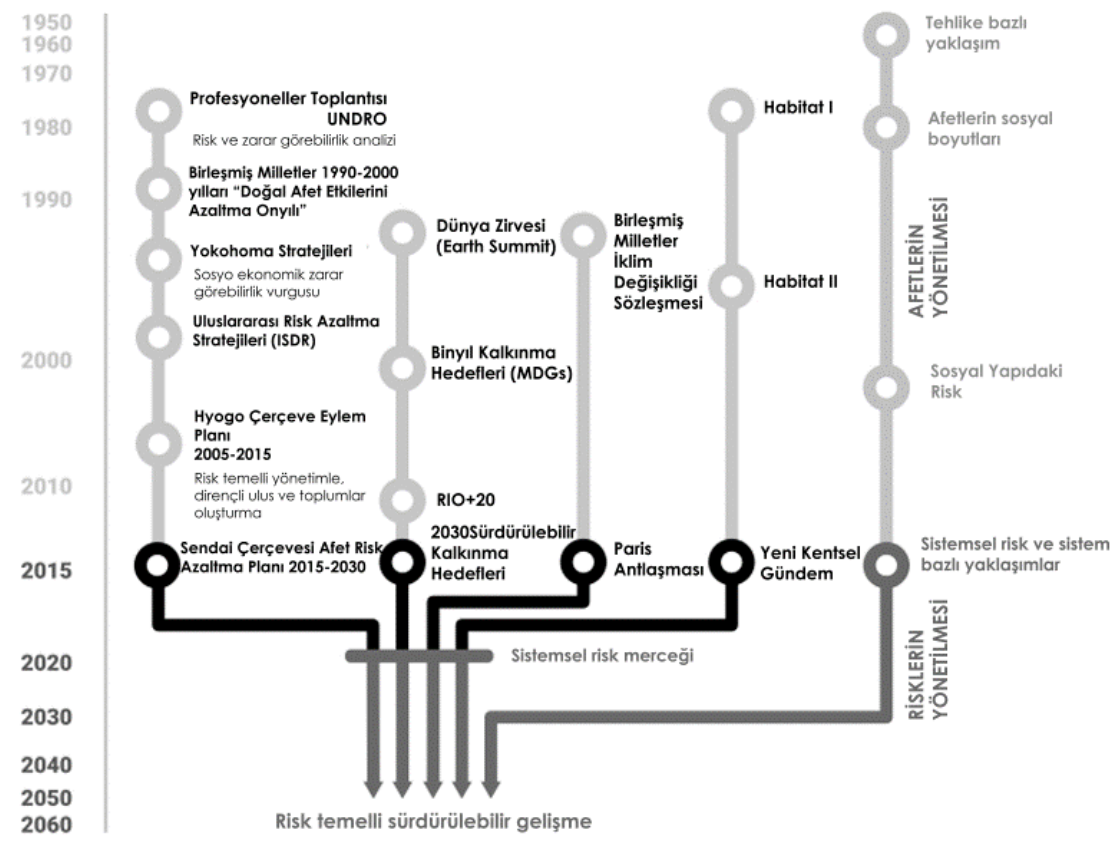

Şekil 1. Afet risklerini azaltmada tarihsel süreç (Kaynak: UNISDR, 2019, s.25'ten çevrilmiştir)

Tüm bu yapılan çalışmalara bakıldığında, sürdürülebilir gelişme için doğal afetlerle ilgili çalışmalar, ekonomi ve çevre ile ilişkili toplantılar, iklim de- 
ğişikliği sözleşmeleri ve kentleri ve yaşamı konu alan diğer çalışmalar birbirleriyle ilişkili olarak sürece dahil edilmiştir. Tüm bu süreçler ekonomik, toplumsal ve ekolojik açıdan beraber değerlendirilmelidir.

\section{Çalışmanın Amacı ve Yöntemi}

Bu çalışmanın amacı, dayanıklılık kapsamında yapılan ölçüm ve değerlendirme çalışmalarının kentsel dayanıklılık ve afet riski açısından öneminin ortaya konulmasıdır. Afet risklerine karşı dayanıklılık modeli oluşturulmasında toplumsal ve mekânsal verileri içeren analiz ve değerlendirme yöntemlerinin irdeleyerek çıkarımlar yapılmasıdır.

Çalışmada dayanıklılık, kentsel dayanıklılık, afet riski, afet yönetimi, dayanıklılığın ölçülmesi ve dayanıklılığın değerlendirilmesi anahtar kelimeleri kullanılarak uluslararası veri tabanı SCOPUS içerisinde dergiler ve kitaplar, ulusal kaynaklardan YÖK'ün ulusal tez merkezi, Dergi Park ve TUBITAK proje dizini taranmış, ikincil veri analizi ve içerik analizi yöntemleri kullanılmıştır. Çalışmada ölçüm yöntemleri ve bunlar arasındaki farklar ortaya konmuştur. Tüm ölçüm yöntemlerine bakıldığında, özellikle kent ölçeğinde yapılan çalışmalara bakılmıştır. Bu çalışmalardan hem toplumsal hem de mekâna yönelik olarak farklı ölçüm araçlarına ve yöntemine sahip üç çalışma seçilmiş ve irdelenmiştir. Bu 3 çalışma, kentte uygulanmış araç, gösterge ve puan kartları özelliklerine sahip yarı kantitatif metotlar olması sebebiyle seçilmiştir. Yapılan bu çalışmanın kentsel dayanıklılık konusunda, afet kapsamında alınacak önlemlere ve uygulanacak politikalara katkı sağlayacağı düşünülmektedir.

\section{Bulgular}

Uluslararası literatürde scopus veri tabanı kullanılarak, dayanıklılık (resilience), afet (disaster), afet yönetimi (disaster management) değerlendirme (assessment), ölçme (measurement) anahtar kelimeleri kullanılmıştır. Buna göre, bu kelimelerin bir arada kullanılarak yapıldığı çalışmaların, 2008 sonrası yapılmaya başlandığı ve 2016 yılında, önceki yıllara göre gözle görülür bir artışla yükseldiği gözlemlenmiştir (Şekil 2). Bu artışın sebebi, 2015 yılında yayınlanan Sendai Çerçeve Eylem Planı, Paris Antlaşması 2030 Sürdürülebilir Kalkınma Hedefleri ve Yeni Kentsel Gündem olduğu söylenebilir. Bu alandaki çalışmalar 2020'ye kadar artış göstermektedir. 


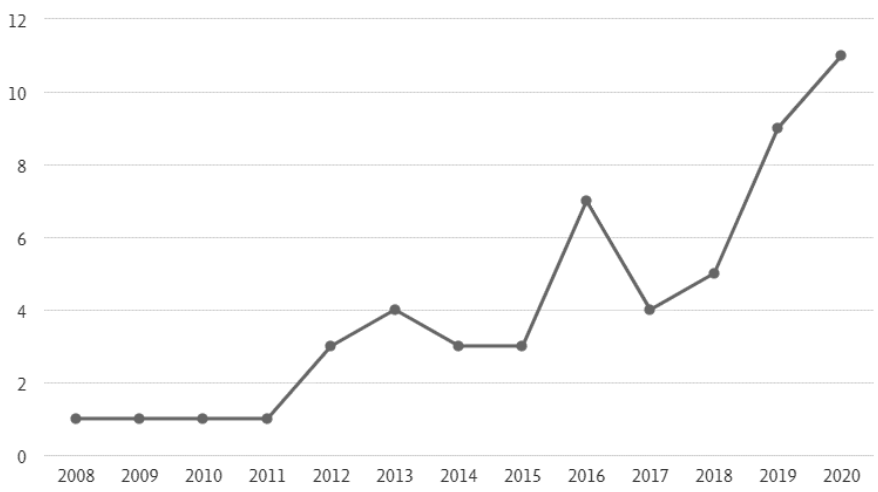

Şekil 2. Dayanıklılık (resilience), afet (disaster), afet yönetimi (disaster management) değerlendirme (assessment), ölçme (measurement) anahtar kelimeleri kullanılarak yapılan çalışmaların yıllara göre dağılımı (Kaynak: Scopus, 2020)

Çalışma alanlarına göre dağılımında, en çok çevre bilimleri (\%23.9), sosyal bilimler (\%18.5) ve mühendislik (\%14.1)'dir (Şekil 3). Diğer alanlarda bu oran gittikçe azalmaktadır.

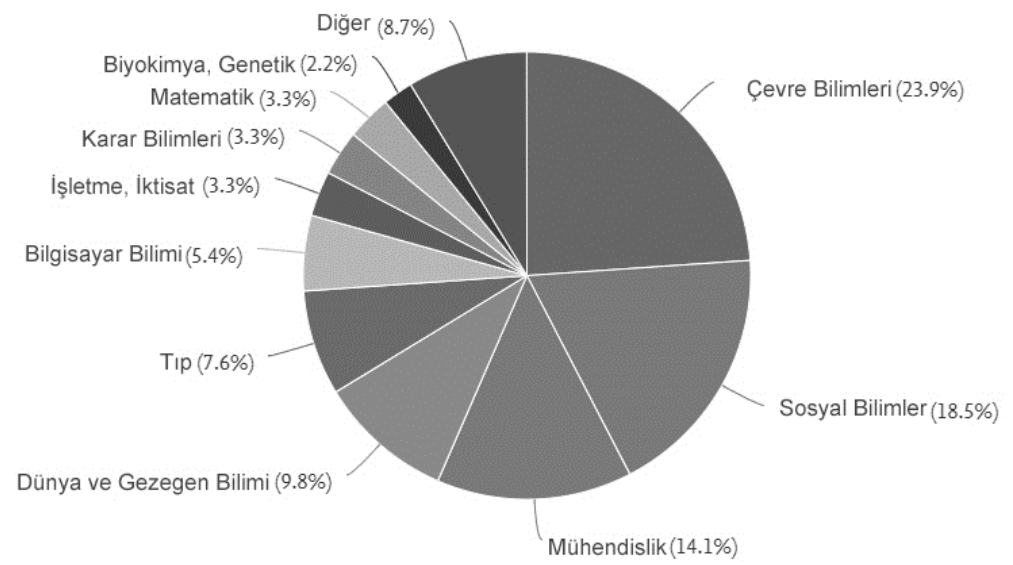

Şekil 3. Çalışma alanlarına göre dağılımı (Kaynak: Scopus, 2020)

Ülkelerin bu alandaki çalışmalarına bakıldığında, son 10 yılda en çok bu konuyu çalışan ülkeler; ABD (16), Çin (7), Avustralya (6), İngiltere (5), Sri Lanka (4), Hindistan (3), İtalya (3), İsrail (2), Japonya (2) ve Hollanda (2) olarak sıralanmıştır (Şekil 4). Sıralamaya giren ülkeler arasında en fazla Amerika Bileşik Devletlerinin, en az ise İsrail, Japonya ve Hollanda'nın bu konuları 
çalıştı̆̆ı görülmektedir. Bunun sebepleri arasında afete ayrılan fon, yüz ölçümü ve afete maruz kalma oranları düşünülmektedir. Türkiye ise bu sıralamada yer bulmamıştır.

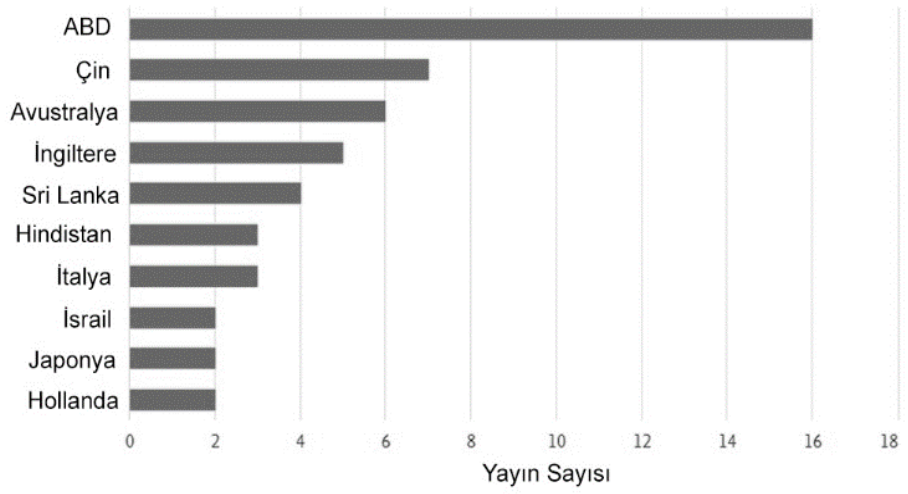

Şekil 4. Ülkelere göre yayın sayıları (Kaynak: Scopus, 2020)

Uluslararası düzeyde mühendislik alanında, Saja, A.M.A., Goonetilleke, A., Teo, M., Ziyath, A.M., çevre bilimlerinde Cutter, S.L., Lam, N.S.N ve Cai, H. öne çıkan araştırmacılar arasındadır (Şekil 5). Her iki disiplinde bulunan araştırmacılar bu alanların yanı sıra, sosyal bilimleri kapsayan toplumsal dayanıklılık kavramını da çalışmalarında kullanmışlardır.

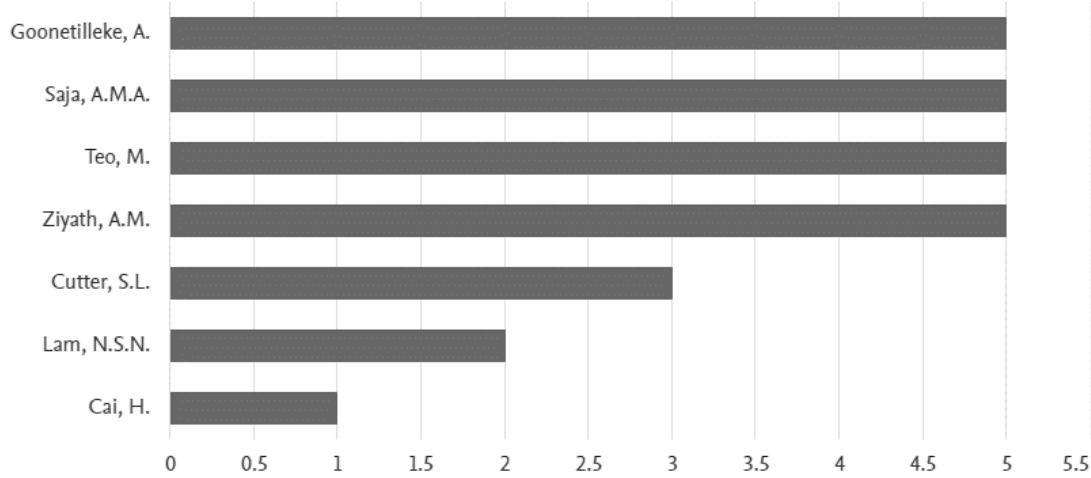

Şekil 5. Araştırmacılar ve yayın sayıları (Kaynak: Scopus, 2020)

Ulusal ve uluslararası yayın sayıları karşılaştırıldığında, Türkiye'de yapılan yayınlar niceliksel olarak az sayıdadır (Tablo 1). Özellikle dayanıklılık, dayanıklılığın değerlendirilmesi ve ölçülmesi ile ilgili daha fazla yayın yapılmasına ihtiyaç duyulmaktadır. 
Tablo 1. Ulusal ve uluslararası veri tabanlarındaki yayın sayıları

\begin{tabular}{lll}
\hline Anahtar kelimeler & $\begin{array}{l}\text { ulusal yayın sayısı (tez merkezi, } \\
\text { dergi park, tubitak, dizin) }\end{array}$ & $\begin{array}{l}\text { uluslararası yayın } \\
\text { sayısı (scopus) }\end{array}$ \\
\hline $\begin{array}{l}\text { dayanıklılık (resilience, } \\
\text { resilient) }\end{array}$ & 754 & 85.413 \\
\hline afet (disaster) & 1.715 & 134.111 \\
\hline $\begin{array}{l}\text { afet yönetimi (disaster } \\
\text { management) }\end{array}$ & 39.702 & 51.530 \\
\hline $\begin{array}{l}\text { dayanıklılığın ölçülmesi } \\
\text { (measurement of } \\
\text { resilience) }\end{array}$ & 11 & 3.906 \\
\hline $\begin{array}{l}\text { dayanıklı̆lı̆ın } \\
\text { değerlendirilmesi } \\
\text { (resilience assessment) }\end{array}$ & 3 & 13.063 \\
\hline
\end{tabular}

Ülkemizdeki araştırmacıların afet, kent ve dayanıklılık ilgili çalışmalardan bazıları şu şekildedir;

Cumhurbaşkanlığı Yerel Yönetim Politikaları Kurulu; T.C. İçişleri Bakanlığ1 Afet ve Acil Durum Yönetimi Başkanlığ1 ve Kent Araştırmaları Enstitüsü (2020) tarafından, "Belediyeler için Afetlere Dirençli Kentler Rehberi" çalışması hazırlanmıştır. Afetlere dirençli kentler oluşturmak için afetleri öncelikle yerelden yürütülmesi düşüncesi ile belediye başkanlarına belirlenen ilkeler çerçevesinde yönetim süreçleri açısından yol gösterici bir kılavuz olması amaçlanmıştır. Bu rehber, Türkiye'nin afet risklerinin azaltılması için uluslararası ve ulusal politika önceliklerine göre oluşturulmuştur.

Adıkutlu (2019) "Afetlere dayanıklılık: Türkiye'deki kentsel dönüşüm deneyimlerinden çıarılan dersler" Şehir ve Bölge Planlama Yüksek Lisans programındaki tezinde afet kanunun dayanıklılık bakımından değerlendirilmesi ve kentsel yenileme faaliyetleri ile ilişkisini çalışmıştır.

Yaman Galantini (2018) “Urban Resilience As a Policy Paradigm for Sustainable Urban Planning and Urban Development: The Case Of Istanbul (Sürdürülebilir Kent Planlama Ve Kentsel Kalkınma İçin Bir Politika Paradigması Olarak Kentsel Dayanıklılık: İstanbul Örneği)“ Şehir ve Bölge Planlama Doktora programındaki çalışmasında, dayanıklılık kavramının kent planlama süreçleriyle entegrasyonu irdelenmiş, İstanbul özelinde model oluşturulmaya çalışılmıştır. Dayanıklı kent planlama politikalarının oluşturulmasından kimin sorumlu olması gerektiğini tespit etmek için uzman anketi yapılmış ve paydaşlar belirlenmiştir. İki aşamalı Delphi anketi kullanılarak İstanbul'un kırılgan bölgeleri tespit edilmiş ve bu bölgelere kamuoyu anketi uygulanmış- 
tır. Daha sonra kentsel dayanıklılık planlaması sürecinin çerçevesinin oluşturulması ve dayanıklılık ilkelerine dayalı kentsel politikalar ve araçların tanımlanması için Delphi'nin ikinci kısmı uygulanarak, kentsel dayanıklılık planlamasının mevcut kentsel planlama gündeminde yer edinmesine yönelik öneriler getirilmiş ve tez kapsamında çalışılan alanlar için model geliştirilmiştir.

Erdinç (2018) "Afetlere karşı kentlerin dirençliliği: İstanbul örneği”, Şehir ve Bölge Planlama Yüksek Lisans programındaki çalışmasında, afet ve doğal afet tanımları, afet yönetimi, tehlike, zarar görebilirlik, risk ve dirençli kent gibi kavramlara yer vermiştir. Afet yönetim mevzuatı, mekânsal planlama mevzuatının afet yönetimine katkısı, afet yönetimi ve mekânsal planlar arasındaki ilişki, kentsel zarar görebilirlik ve kentsel riskler değerlendirilmiş ve afete dayanıklılık kapsamında İstanbul tehlike, zarar görebilirlik, risk ve zarar azaltma kapsamında irdelemiştir.

Karahan (2018), “Dirençli kentler bağlamında Karaman kentinin değerlendirilmesi" Peyzaj Mimarlığı Yükssek Lisans programındaki çalışmasında, Dirençli Kentler Hareketi ve Ekokent ölçütleri ile ilişkili kavramsal çerçevenin Karaman'da uygulanmasını iredeleyerek, bölgesel, ulusal ve uluslararası strateji, plan ve programlar kapsamında değerlendirmiştir.

Balta (2013) “Kentsel risklerin planlama temelinde analizi ve dirençli kent planlama yaklaşımı" Şehir ve Bölge Planlama Doktora programındaki çalışmasında, dayanıklı kentsel yerleşimlere erişmede benimsenecek ilkelerin belirlenmesi için afetler ve planlama alanındaki uzmanların değerlendirmeleri ve analitik hiyerarşi süreci (AHS) yöntemi ile gösterge ağırlıkları oluşturmuştur. Bu doğrultuda, kentsel dayanıklılığın önemli bileşenlerini oluşturan tehlike, korunmasızlık, risk azaltma kapasitesi, acil müdahale ve yara sarma kapasitesini tanımlayan bir endeks çıarmıştır. Çıkan sonuçlara göre yasal-yönetsel, fiziksel, çevresel, sosyo-ekonomik boyutta planlama ve uygulama stratejileri geliştirmiştir.

Uluslararası ölçüm ve değerlendirme örneklerinin, ulusal düzeyde tam olarak karşılığ bulunmamakla beraber, Yaman Galantini (2018)'nin doktora tezinde mekânsal olarak kırılgan alanlar ele alınarak değerlendirme çalışması yapılmıştır. Diğer araştırmalarda dayanıklılık kavramı farklı şekillerde çalışılmıştır. Bu kavram, afet risklerini azaltma, kapasite belirleme ve adaptasyon yeteneği incelenerek farklı yöntemlerle ele alınmaktadır. 


\section{Dayanıklılık ölçüm yöntemleri}

Afete karşı dayanıklılık çalışmalarında, en önemli sorunlardan birisi ölçülmesi ve değerlendirilmesidir. Dayanıklılık ölçme metotları bakımından kalitatif ve kantitatif olmak üzere iki kategoriye ayrılmıştır (Şekil 6).

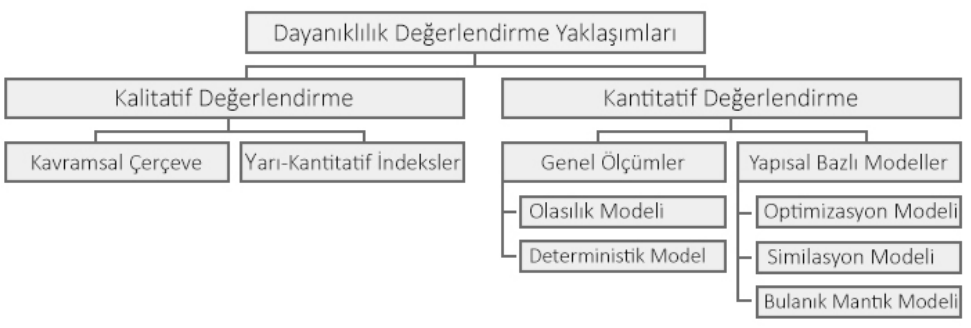

Şekil 6. Dayanıklık ÖlçmeMetotlan(Kaynak:Hosseini, BarkerveRamirez-Marquez2016, s.51'dençevrilmiştir)

Dayanıklılığın çeşitli boyutlarda ele alınması ve çalışılacak ölçek bakımından literatürde oldukça farklı değerlendirme yöntemleri yer almaktadır. Afete karşı dayanıklılığı ölçmek için mekâna, odaklanılan konuya, kapasiteye, karaktere göre yöntemler çeşitlenmektedir. Belirlenen standartlara göre yapılan değerlendirmeler yarı kantitatif göstergeleri içeren, endeks, araç ve puan çizelgesi şeklinde yapılmaktadır (Şekil 7). Yöntemsel olarak, alttan üste yaklaşım (bottom-up approach) daha çok kalitatif yöntem olarak, kurum ve yönetimlerin dayanıklılığını ölçmek için kullanılan yöntemler arasındadır. Üstten alta (top-down approach) ise sıklıkla kantitatif yöntemler arasındadır ve ülke, bölge, eyaleti kent ölçeği için daha uygun bir yöntemdir (Cutter, 2016, s.748).

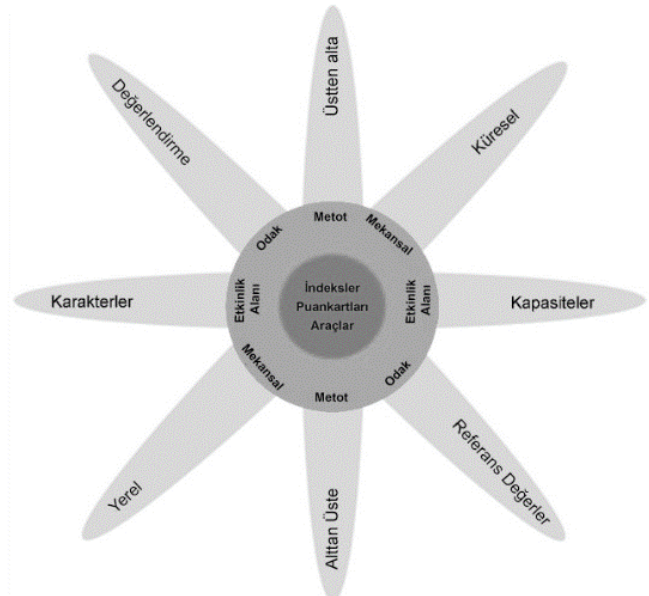

Şekil 7. Dayanıklılık Ölçüm Modelleri (Kaynak: Cutter, 2016, s.748'den uyarlanmıştır) 
Endeksler, çoklu göstergeleri tek bir değerde toplayarak gözlemleri veya ölçümleri özetleyen istatistiksel bir yaklaşımdır. Puan kartları, bir hedefe yönelik performans veya ilerlemenin değerlendirilmesini sağlar. Bu tür yaygın olarak kullanılan bir yöntem, dayanıklılıkla ilgili öğelerin ve eylemlerin varlığı veya yokluğu ile ilgili bir dizi kontrol listesi niteliği taşır. Daha sonra, öğelerin ne sıklıkta bulunduğuna, kullanıldığına vb. dayalı bir puan üretilir. Puan kartları normalde nitel değerlendirmelere dayanır ve daha sonra puanlara dönüştürülürken, çoğunlukla endeks değerini elde etmek için nicel veriler kullanır. Araçlar, örnek prosedürlerde, anket araçlarında veya puan kartlarının endekslerinin derlenmesinde kullanılacak veriler, dayanıklılı̆̆ değerlendirmede rehber oluşturması için kullanılır (Cimellaro, 2016, s.50).

Ölçüm çeşitleri tip, alan, odak, etki alanı ve yöntemine göre 5 sinıfta incelenmiştir. Ölçme tipi olarak araç, indeks ve puan kartları kullanılmıştır. Kullanılan ölçümler ülke, ülkeler arası, kent, topluluk, kıyı alanları, altyapı (sosyal), metro alanlarında gerçekleştirilmiştir. Odaklandığında referans değerler veya değerlendirme metoduna başvurulmuştur. Etki alanı olarak, kapasite, karakter, her ikisi ve kurumsal durum ölçülmüştür. Ölçek yöntemi olarak, alttan üste doğru veya üstten alta doğru değerlendirilmiştir. Her çalışma yapıldığı alana göre farklılıklar taşıdığı için kullanılan yöntemler çeşitlilik göstermektedir. Tablo 2'de Dünya' da yapılan çeşitli dayanıklılık ölçüm çeşitleri sıralanmıştır.

Tablo 2. Dayanıklılık Ölçüm Çeşitleri ve Sınıflandırılması (Kaynak: Cutter, 2016, s.746-747)

\begin{tabular}{|c|c|c|c|c|c|}
\hline \multicolumn{6}{|c|}{ Dayanıklılık Ölçüm Çeşitleri } \\
\hline $\begin{array}{l}\text { Ölçüm Adı } \\
\text { (Araştırmacılar) }\end{array}$ & Tip & $\begin{array}{l}\text { Mekansal/ } \\
\text { Çalışma } \\
\text { Alanı }\end{array}$ & Odak & Etki Alanı & Yöntem \\
\hline $\begin{array}{l}\text { ASPIRE (Dünya } \\
\text { Bankası 2015) }\end{array}$ & Araç & Ülke & $\begin{array}{l}\text { Referans } \\
\text { Değerler } \\
\end{array}$ & Kurumsal & $\begin{array}{l}\text { Üstten } \\
\text { alta }\end{array}$ \\
\hline $\begin{array}{l}\text { BRIC (Cutter vd., } \\
2010,2014)\end{array}$ & İndeks & ABD kentleri & $\begin{array}{l}\text { Referans } \\
\text { Değerler }\end{array}$ & Karakteristik & $\begin{array}{l}\text { Üstten } \\
\text { alta }\end{array}$ \\
\hline $\begin{array}{lr}\text { CART } & \text { (Pfefffer- } \\
\text { baum } & \text { vd., } \\
2011,2013) & \\
\end{array}$ & Araç & Topluluklar & $\begin{array}{l}\text { Referans } \\
\text { Değerler }\end{array}$ & Kapasiteler & $\begin{array}{l}\text { Alttan } \\
\text { üste }\end{array}$ \\
\hline $\begin{array}{ll}\text { CCRAM } & \text { (Cohen } \\
\text { vd., 2013) } & \\
\end{array}$ & Araç & Topluluklar & $\begin{array}{l}\text { Referans } \\
\text { Değerler }\end{array}$ & Kapasiteler & $\begin{array}{l}\text { Alttan } \\
\text { üste }\end{array}$ \\
\hline $\begin{array}{l}\text { CDRI (Peacock ve } \\
\text { diğ., 2010) }\end{array}$ & İndeks & $\begin{array}{ll}\text { ABD k1y1 } \\
\text { kentleri }\end{array}$ & $\begin{array}{l}\text { Referans } \\
\text { Değerler }\end{array}$ & Karakteristik & $\begin{array}{l}\text { Üstten } \\
\text { alta }\end{array}$ \\
\hline $\begin{array}{l}\text { Coastal } \\
\text { Indesilience } \\
\text { vd., 2010) } \\
\text { vempier } \\
\end{array}$ & $\begin{array}{l}\text { Puan } \\
\text { kartı }\end{array}$ & Topluluklar & $\begin{array}{l}\text { Referans } \\
\text { Değerler }\end{array}$ & Kapasiteler & $\begin{array}{l}\text { Alttan } \\
\text { üste }\end{array}$ \\
\hline $\begin{array}{l}\text { CoBRA } \\
\text { 2014) }\end{array}$ & Araç & Topluluklar & $\begin{array}{l}\text { Referans } \\
\text { Değerler }\end{array}$ & $\begin{array}{l}\text { Kapasiteler/Karak- } \\
\text { teristik }\end{array}$ & $\begin{array}{l}\text { Alttan } \\
\text { üste }\end{array}$ \\
\hline
\end{tabular}




\begin{tabular}{|c|c|c|c|c|c|}
\hline \begin{tabular}{lr}
\multicolumn{2}{l}{ Community Resili- } \\
ent & System \\
(CARRI & 2013; \\
White vd., 2015)
\end{tabular} & Araç & Topluluklar & $\begin{array}{l}\text { Referans } \\
\text { Değerler }\end{array}$ & Kapasiteler & $\begin{array}{l}\text { Alttan } \\
\text { üste }\end{array}$ \\
\hline $\begin{array}{l}\text { Community Resi- } \\
\text { lience Index (Sher- } \\
\text { rieb vd., 2010) }\end{array}$ & İndeks & Topluluklar & $\begin{array}{l}\text { Referans } \\
\text { Değerler }\end{array}$ & Karakteristik & $\begin{array}{l}\text { Üstten } \\
\text { alta }\end{array}$ \\
\hline $\begin{array}{ll}\text { CREAT } & \text { (USEPA } \\
\text { 2015) } & \\
\end{array}$ & Araç & $\begin{array}{l}\text { Altyapı (sos- } \\
\text { yal) }\end{array}$ & $\begin{array}{l}\text { Değerlen- } \\
\text { dirme }\end{array}$ & Karakteristik & $\begin{array}{l}\text { Üstten } \\
\text { alta }\end{array}$ \\
\hline $\begin{array}{l}\text { DFID Resilience } \\
\text { (Twigg, 2009) }\end{array}$ & Araç & Ülke & $\begin{array}{l}\text { Referans } \\
\text { Değerler } \\
\end{array}$ & Karakteristik & $\begin{array}{l}\text { Alttan } \\
\text { üste } \\
\end{array}$ \\
\hline $\begin{array}{l}\text { FAO Livelihoods } \\
\text { (Alinvovi vd., } \\
2010)\end{array}$ & İndeks & Topluluklar & $\begin{array}{l}\text { Referans } \\
\text { Değerler }\end{array}$ & Karakteristik & $\begin{array}{l}\text { Alttan } \\
\text { üste }\end{array}$ \\
\hline $\begin{array}{lr}\text { Financial } & \text { System } \\
\text { Resilience } & \text { (Berry } \\
\text { vd, 2015) } & \\
\end{array}$ & İndeks & $\begin{array}{l}\text { Altyap1 (sos- } \\
\text { yal) }\end{array}$ & $\begin{array}{l}\text { Değerlen- } \\
\text { dirme }\end{array}$ & Karakteristik & $\begin{array}{l}\text { Üstten } \\
\text { alta }\end{array}$ \\
\hline $\begin{array}{l}\text { FM Global Resi- } \\
\text { lience (Oxford } \\
\text { Metrica 2015) }\end{array}$ & İndeks & $\begin{array}{l}\text { Altyap1 (sos- } \\
\text { yal) }\end{array}$ & $\begin{array}{l}\text { Değerlen- } \\
\text { dirme }\end{array}$ & Karakteristik & $\begin{array}{l}\text { Üstten } \\
\text { alta }\end{array}$ \\
\hline NIST (NIST 2015) & Araç & $\begin{array}{l}\text { Altyapı (sos- } \\
\text { yal) }\end{array}$ & $\begin{array}{l}\text { Referans } \\
\text { Değerler }\end{array}$ & Karakteristik & $\begin{array}{l}\text { Üstten } \\
\text { alta }\end{array}$ \\
\hline $\begin{array}{l}\text { Oxfam GB (Hug- } \\
\text { hes ve Bushell, } \\
\text { 2013) }\end{array}$ & İndeks & Topluluklar & $\begin{array}{l}\text { Referans } \\
\text { Değerler }\end{array}$ & Kapasiteler & $\begin{array}{l}\text { Alttan } \\
\text { üste }\end{array}$ \\
\hline $\begin{array}{l}\text { PEOPLES } \\
\text { (Renschler vd., } \\
\text { 2010) }\end{array}$ & Araç & Topluluklar & $\begin{array}{l}\text { Referans } \\
\text { Değerler }\end{array}$ & Kapasiteler & $\begin{array}{l}\text { Üstten } \\
\text { alta }\end{array}$ \\
\hline $\begin{array}{l}\text { RCI (Pendall vd., } \\
\text { 2010) }\end{array}$ & İndeks & $\begin{array}{l}\text { ABD metro } \\
\text { alanları }\end{array}$ & $\begin{array}{l}\text { Referans } \\
\text { Değerler }\end{array}$ & Karakteristik & $\begin{array}{l}\text { Üstten } \\
\text { alta }\end{array}$ \\
\hline $\begin{array}{l}\text { ResilUS (Miles ve } \\
\text { Chang 2011) }\end{array}$ & Araç & Kent & $\begin{array}{l}\text { Değerlen- } \\
\text { dirme }\end{array}$ & Kapasiteler & $\begin{array}{l}\text { Üstten } \\
\text { alta }\end{array}$ \\
\hline $\begin{array}{lcc}\text { RMI } & \text { (Fisher } & \text { vd., } \\
\text { 2010; } & \text { Petit } & \text { vd., } \\
\text { 2013) } & & \\
\end{array}$ & $\begin{array}{l}\text { İn- } \\
\text { deks/Ar } \\
\text { aç } \\
\end{array}$ & $\begin{array}{l}\text { Altyapı (sos- } \\
\text { yal) }\end{array}$ & $\begin{array}{l}\text { Değerlen- } \\
\text { dirme }\end{array}$ & Karakteristik & $\begin{array}{l}\text { Üstten } \\
\text { alta }\end{array}$ \\
\hline $\begin{array}{l}\text { Rockefeller } 100 \text { re- } \\
\text { silient cities } \\
\text { (ARUP ve Rocke- } \\
\text { feller 2014) }\end{array}$ & Araç & Topluluklar & $\begin{array}{l}\text { Referans } \\
\text { Değerler }\end{array}$ & Kapasiteler & $\begin{array}{l}\text { Alttan } \\
\text { üste }\end{array}$ \\
\hline $\begin{array}{l}\text { RRI (Cox ve Ham- } \\
\text { len, 2015) }\end{array}$ & İndeks & Topluluklar & $\begin{array}{l}\text { Referans } \\
\text { Değerler }\end{array}$ & Kapasiteler & $\begin{array}{l}\text { Alttan } \\
\text { üste }\end{array}$ \\
\hline $\begin{array}{l}\text { TNC Coastal Resi- } \\
\text { lience (TNC 2015) }\end{array}$ & Araç & Kıyı Alanları & $\begin{array}{l}\text { Referans } \\
\text { Değerler }\end{array}$ & Kurumsal & $\begin{array}{l}\text { Üstten } \\
\text { alta }\end{array}$ \\
\hline $\begin{array}{l}\text { UNISDR Resilient } \\
\text { Cities (UNISDR } \\
\text { 2013, 2016) } \\
\end{array}$ & Araç & Kentler & $\begin{array}{l}\text { Referans } \\
\text { Değerler }\end{array}$ & Kapasiteler & $\begin{array}{l}\text { Alttan } \\
\text { üste }\end{array}$ \\
\hline $\begin{array}{l}\text { USAID Resilience } \\
\text { (USAID 2013) }\end{array}$ & Araç & Ülkeler & $\begin{array}{l}\text { Referans } \\
\text { Değerler } \\
\end{array}$ & Kapasiteler & $\begin{array}{l}\text { Alttan } \\
\text { üste } \\
\end{array}$ \\
\hline
\end{tabular}




\section{Topluluklar için temel dayankkllık göstergeleri -BRIC model (Baseline} resilience indicators for communities)

Bu modeli, yerle ilişkili toplumsal dayanıklılık boyutunu ölçmek için Cutter vd (2008) üretmişlerdir. Modelin uygulanması için bazı göstergeler belirlenmiş ve bunların ölçülmesiyle dayanıklılık seviyelerinin belirlenebileceği öngörülmüştür. Temel koşullarda belirtilen toplumsal dayanıklılık kriterleri 6 temel başlık altında incelenmiştir. Bunlar; ekolojik, sosyal, ekonomik, kurumsal, altyapısal, toplumsal kabiliyet olarak belirtilmiştir. 6 temel başlığın her birisi kendi içerisinde afete yönelik barındırması gereken özelliklerle alt başlıklara ayrılmıştır, verilerin içeriğine göre kantitatif ve kalitatif yöntemlerle bilgi akışı gerçekleşmektedir (Cutter vd, 2008,s.602).

Tablo 3'te olası referans kriterleri yer almaktadır. Bu kriterler çalışma alanı ve mekânına göre farklı referans değerleri eklenerek veya çıkarılarak değerlendirilebilir.

Tablo 3. BRIC Model Kriterleri (Kaynak: Cutter vd, 2008,s.604)

\begin{tabular}{ll}
\hline Boyutlar & Olası Değerler \\
\hline Ekolojik & Sulak alan miktarı ve kayıpları \\
& Erozyon oranı \\
& Geçirimsiz yüzey oranı \\
& Biyoçeşitlilik \\
& Kiyı koruma planı \\
\hline Sosyal & Demografik yapı (yaş, cinsiyet, iş, sınıf, maaş) \\
& Sosyal ağlar ve sosyal kapsayıcılık \\
& Toplumsal değerler -bağlılık \\
& İnanç temelli organizasyonlar (dernekler) \\
\hline Ekonomik & İş gücü \\
& Emlak değeri \\
& Zengin nesil durumu \\
& Belediye finansal yapı ve yenilenmesi \\
\hline Kurumsal & Tehlike azaltma programlarına katılım \\
& Tehlike önleme planları \\
& Acil servisler \\
& Zonlama ve yapı standartları \\
& Acil durum planları \\
& Uyumlu haberleşme ağları \\
& Harekât planlarının sürekliliği \\
\hline Toplumsal & Kritik ve hayati altyapı sistemi \\
& Ulaşım ağları \\
& Konut stoğu ve yaşı \\
& Ticari ve sanayi kuruluşlar \\
\hline Altyapı & Yerel risk farkındalığı \\
& \\
\hline
\end{tabular}




\section{Rehberlik servisi \\ Fizyopatolojik hastalıkların olması (Alkol, uyuşturucu, çeşitli bağımlılıklar) \\ Sağlık ve iyi yaşam koşulları (mental sağlık durumu, stresle ilişkili durumlar) \\ Yaşam kalitesi (yüksek memmuniyet)}

\section{Dayanıklı kent göstergeleri (Arup \& Rockefeller Foundation)}

Bir kentte yoksulluk, sosyal düzen eksiklikleri ile birlikte yetersiz altyapı varsa ve tüm bunlara ilaveten yönetim anlamında zayıfsa bu kent yeterli dayanıklılığa sahip değildir. ARUP ve Rockefeller Vakfı (2015) tarafından seçilen bu modelde bir kentin dayanıklı olabilmesi için dört boyut, on iki hedef, elli iki gösterge ve yedi nitelik belirlenmiştir. Bu dört boyut; Sağlık ve Refah, Ekonomi ve Toplum, Altyapı ve Çevre, Liderlik ve Stratejidir. Sağlık ve Refah boyutunun hedefleri; Minimum Hasar Görebilirlik, İsgücü ve İş Sahası Çeşitliliği, İnsan Sağlı̆̆ı ve Yaşamı İçin Yeterli Tedbirlerdir (Şekil 8). Ekonomi ve Toplum boyutunun hedefleri; Kolektif Kimlik ve Karş1lıkı Destek, Sosyal İstikrar ve Güvenlik, Finansal Kaynakların Erişilebilirliği ve Afet Fonlarıdır. Altyapı ve Çevre boyutunun hedefleri; Azaltılmış Fiziksel Riskler ve Hasar Görebilirlik, Güvenilir İletişim ve Hareketlilik, Altyapı ve Ekosistemin Devamlılığıdır. Liderlik ve Strateji boyutunun hedefleri; Etkin Liderlik ve Yönetim, Güçlendirilmiş Paydaşlar, Entegre Gelişim Planlamasıdır (ARUP ve Rockefeller Foundation, 2015; Şirin Dinçer, 2016).

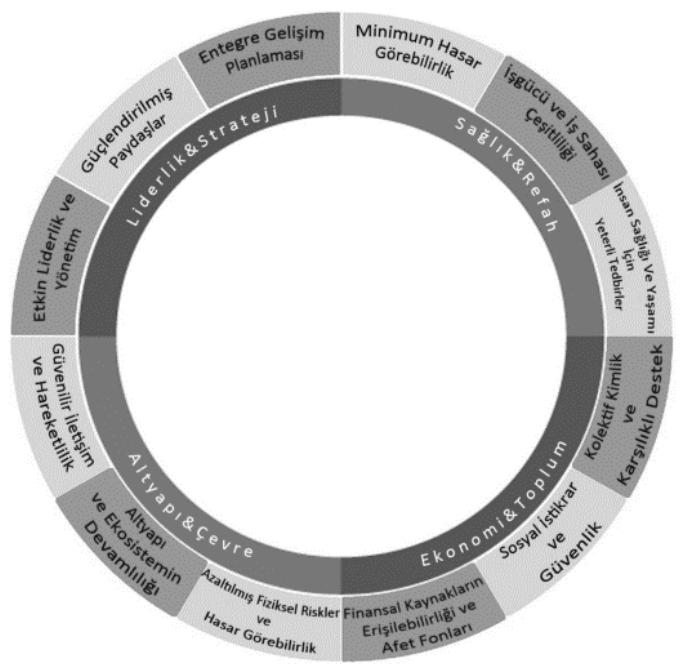

Şekil 8. Kentsel Dayanıklllkk Modeli (Kaynak: ARUP ve Rockefeller Foundation, 2015; Şirin Dinçer, 2016) 
ARUP ve Rockefeller Foundation (2015)'in geliştirdiği kentsel dayanıklılık modelinde 4 boyut, 12 hedef ve 52 gösterge vardır. Bu göstergeleri değerlendirmek için kalite kriterleri derecelendirilerek, karakterleri belirlenmiştir. Bunlar;

- Esnek (Filexible)

- Yedek (Redundant)

- Sağlam (Robust)

- Becerikli (Resourceful)

- Yanstici (Reflective)

- Dahil Edici (Inclusive)

- Entegre (Integrated) olarak kentin yapısı ile ilgili de bilgi vermektedir.

Kentler için afete dayamkllik puan kartlarn (UNISDR the disaster resilience scorecard for cities)

Birleşmiş Milletlerin Dayanıklı Kentler için hazırladığı yöntemde puan kartı, yerel yönetimlerin Sendai Afet Riskini Azaltma Çerçevesi: 2015-2030 uygulamasındaki ilerlemeyi ve zorlukları izlemesine ve gözden geçirmesine ve afete dayanıklılıklarını değerlendirmesine olanak tanıyan bir dizi değerlendirme sunmaktadır. UNISDR (2017, s.4)'de Dayanıklı Kentleri 10 temel esas etrafında yapılandırılmıştır (Şekil 9).
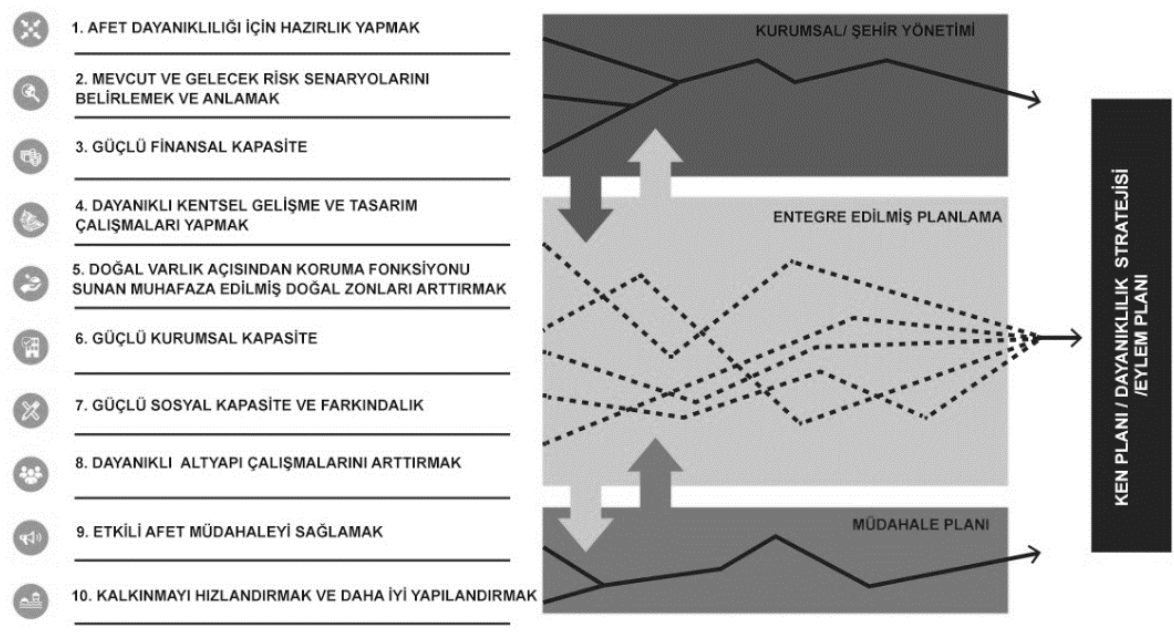

On temel esasın ilk üç maddesinde bahsedilen afet ve risklerle ilgili hazırlıklar, kurumsal durum ve şehir yönetimiyle ilgilidir. Dördüncü madde ve sekizinci maddelerde dayanıklılık için planlama, koruma, tasarım, kapasite 
arttırma, altyapı ve toplumsal çalışmalar entegre edilmiş planlamaları gerektirmektedir. Son iki madde ise, güçlü ve etkili müdahale ve kalkınma çalışmaları dayanıklı kentler için herhangi bir afet durumunda yol haritası çizmeyi gerektiren planlar için esaslardır. Bu üç yapı kent planı, dayanıklılık stratejisi ve eylem planları için beraber çalışan sistemlerdir.

\section{Sonuç}

Dünyada yapılan dayanıklılık ve afet çalışmalarına bakıldığında, ölçek olarak yerel veya küresel düzeyde, alanın karakterinin veya kapasitesinin değerlendirildiği, analizlerin kriterlerle veya referans değerleriyle yapıldığı yarı kantitatif yöntemlere rastlanılmıştır. Bu ölçümler, araç, gösterge ve puan kartları ile yapılmıştır. Amerika'nın Ulusal Standartlar ve Teknoloji Enstitüsü (NIST) (2015) göre kapsayıcılık, kullanılabilirlik, etki değerlendirmesi, kullanılan teknikler ve kritik değerlendirme kriterlerine göre bu üç çalışmadan Tablo 4'teki sonuçlar çıkmıştır.

Tablo 4. Ölçüm modellerinin karşılaştırılması (Kaynak: NIST, 2015)

\begin{tabular}{|c|c|c|}
\hline $\begin{array}{l}\text { Topluluklar için temel daya- } \\
\text { nıklılık göstergeleri -BRIC } \\
\text { model (Baseline resilience in- } \\
\text { dicators for communities) }\end{array}$ & $\begin{array}{l}\text { Dayanıklı kent göster- } \\
\text { geleri (Arup \& Rocke- } \\
\text { feller Foundation) }\end{array}$ & $\begin{array}{l}\text { Kentler için afete dayanıklılık } \\
\text { puan kartları (UNISDR the di- } \\
\text { saster resilience scorecard for } \\
\text { cities) }\end{array}$ \\
\hline \multicolumn{3}{|l|}{ Kapsayıcılık } \\
\hline $\begin{array}{l}\text { Toplumsal ölçek ve tehlikeler } \\
\text { açısından geniş bir yelpazeye } \\
\text { sahiptir. } \\
\text { İyileşme süresi ve zamanı öl- } \\
\text { çeği bilgileri eksiktir. } \\
\text { Sistem ve dayanışma konula- } \\
\text { rında belirli sınırlandırmalar } \\
\text { vardır. }\end{array}$ & $\begin{array}{l}\text { Toplumsal ölçek, tehli- } \\
\text { keler, iyileşme süresi, } \\
\text { sistemse bilgiler ve da- } \\
\text { yanı̧ma konularında } \\
\text { geniş bir yelpaze sahip- } \\
\text { tir. Fakat dayanışma } \\
\text { kavramında belirli bir } \\
\text { çerçeve çizilmesine ih- } \\
\text { tiyaç vardır. }\end{array}$ & $\begin{array}{l}\text { Toplumsal ölçek ve tehlikeler } \\
\text { açısından geniş bir yelpaze sa- } \\
\text { hiptir. } \\
\text { İyileşme süresi ve zaman ölçeği } \\
\text { için ek bilgiler gerekmektedir. } \\
\text { Sistemsel bilgiler eksiktir. } \\
\text { Karşılıklı dayanışma konusun- } \\
\text { dan bahsedilmemektedir. }\end{array}$ \\
\hline \multicolumn{3}{|l|}{ Kullanılabilirlik } \\
\hline $\begin{array}{l}\text { Kullanıcı dostudur. Rahatlıkla } \\
\text { kullanılabilir. } \\
\text { Kamusal hizmetler açısından } \\
\text { orta derece kolaylıklar sağlar } \\
\text { ve ek bilgilere ihtiyaç vardır. } \\
\text { Dayanıklı planlama için sağla- } \\
\text { nan çıtılarda ek bilgiler ge- } \\
\text { rekmektedir. }\end{array}$ & $\begin{array}{l}\text { Diğer yöntemlere göre } \\
\text { daha az kullanıcı dos- } \\
\text { tudur. } \\
\text { Kamusal hizmetler açı- } \\
\text { sindan orta derecede } \\
\text { kolaylıklar sağlar. } \\
\text { Dayanıklı planlama } \\
\text { için çıktılar çok yeterli- } \\
\text { dir. }\end{array}$ & $\begin{array}{l}\text { Kullanıcı dostudur. Rahatlıkla } \\
\text { kullanılabilir. } \\
\text { Kamusal hizmetler açısından } \\
\text { yüksek kolaylıklar sağlar. } \\
\text { Dayanıklı planlama için çıtılar } \\
\text { uygundur. }\end{array}$ \\
\hline
\end{tabular}




\begin{tabular}{|c|c|c|}
\hline \multicolumn{3}{|l|}{ Etki Değerlendirmesi } \\
\hline $\begin{array}{l}\text { Fiziksel etki, sosyal etki ve eko- } \\
\text { nomik etkinin iyileşme süre- } \\
\text { siyle olan ilişkisini kısmen } \\
\text { veya dolaylı yoldan değerlen- } \\
\text { dirir. }\end{array}$ & $\begin{array}{l}\text { Fiziksel etki ve iyi- } \\
\text { leşme süresini kısmen } \\
\text { ve dolaylı olarak de- } \\
\text { ğerlendirirken, ekono- } \\
\text { mik ve sosyal etkinin } \\
\text { iyileşme süresiyle iliş- } \\
\text { kisini açılıkla değer- } \\
\text { lendirir. }\end{array}$ & $\begin{array}{l}\text { Fiziksel etki, sosyal etki ve eko- } \\
\text { nomik etkinin iyileşme süresiyle } \\
\text { olan ilişkisini kısmen veya do- } \\
\text { laylı yoldan değerlendirir. }\end{array}$ \\
\hline \multicolumn{3}{|l|}{ Kullanılan Teknikler } \\
\hline $\begin{array}{l}\text { Mevcut ulusal veri setleri kul- } \\
\text { lanılır. }\end{array}$ & $\begin{array}{l}\text { Kontrol listesi, müla- } \\
\text { katlar, saha çalışmaları } \\
\text { ve derecelendirme kul- } \\
\text { lanılır. }\end{array}$ & $\begin{array}{l}\text { Kontrol listesi ve derecelen- } \\
\text { dirme kullanilır. Fiziksel dene- } \\
\text { tim, mühendislik analizleri veya } \\
\text { uzman görüşüne başvurmak } \\
\text { opsiyoneldir. }\end{array}$ \\
\hline \multicolumn{3}{|l|}{ Kritik Değerlendirme } \\
\hline $\begin{array}{l}\text { Güçlü bir olgunluğa erişmiş } \\
\text { bir yöntem. } \\
\text { Farklı ve yenilikçi olma düzeyi } \\
\text { yüksektir. } \\
\text { Tekrarlanabilir ve tarafsız ol- } \\
\text { ması güçlüdür. } \\
\text { Bilimsel liyakat açısından de- } \\
\text { ğerlendirilmemiştir. }\end{array}$ & $\begin{array}{l}\text { Orta derecede bir yön- } \\
\text { tem. } \\
\text { Farklı ve yenilikçi olma } \\
\text { düzeyi orta. } \\
\text { Tekrarlanabilir ve ta- } \\
\text { rafsız olması güçlüdür. } \\
\text { Bilimsel liyakat açısın- } \\
\text { dan güçlü fakat ek bil- } \\
\text { gilere ihtiyaç vardır }\end{array}$ & $\begin{array}{l}\text { Orta derecede bir yöntem. } \\
\text { Farklı ve yenilikçi olma düzeyi } \\
\text { orta. } \\
\text { Tekrarlanabilir ve tarafsız ol- } \\
\text { ması orta derecededir. } \\
\text { Bilimsel liyakat açısından zayıf- } \\
\text { tır. }\end{array}$ \\
\hline
\end{tabular}

Tüm kriterler değerlendirildiğinde, kentsel dayanıklılık açısından, Topluluklar İçin Temel Dayanıklılık Göstergeleri (BRIC model), kapsayıclığının yüksek olması, kullanım açısından kolaylık sağlaması, etki değerlendirmesinin ortalama olması, mevcut veri setlerinin göstergelerle uygun olması, farklı, tekrarlanabilir, tarafsız ve bilimsel olarak da kendini kanıtlamış bir model olması açısından diğerlerine göre daha anlaşılır bir yöntemdir. Hem mekâna dair hem de topluluklarla ilgili bilgilere ulaşılabilir. Dayanıklı Kent Göstergeleri (Arup \& Rockefeller Foundation), biraz daha kompleks bir sistem sunmaktadır. Kullanıcı açısından veri toplama ve değerlendirme kısmında birden fazla yöntem gerekebilir; fakat net ve açılayıcı bilgilere erişilir. Kentler İçin Afete Dayanıklılık puan kartları (UNISDR the disaster resilience scorecard for cities), geliştirilmesi gereken bir modeldir. Kent ve topluluklardan çok, yönetim ve kentin geneli hakkında bilgiler sunar. 
Yerel yönetimlere kılavuzluk etmesi açısından rehberler, ölçme ve değerlendirme teknikleri hazırlık aşamasında önemli ölçüde yol gösterici olmaktadır. Bu sebeple seçilen bu üç örnekten yerelden uluslararası düzeye kadar afetlerin getireceği olumsuz sonuçları önlemek ve mevcut durumu görmek için Kentler İçin Afete Dayanıklılık Puan Kartları (UNISDR the disaster resilience scorecard for cities), uygulanarak yerel yönetimlerin afetlere karşı dayanıklılık durumu ortaya koyulabilir. Ayrıca afet konusunda uzmanlardan, sivil toplum kuruluşlarından ve halktan oluşan topluluklar oluşturularak bu üç modelle beraber yere özgü yeni modeller geliştirilerek afet öncesi, afet s1rası ve sonrasındaki süreçler için çalışmalar yapılmalıdır.

Kentsel mekânda yapılacak olan çalışmalar için, tek bir ölçüm örneği yerine birkaç farklı modeli kullanarak kentsel dayanıklılık ölçümü ve değerlendirilmesi yapılmalıdır. Mekâna, topluma ve afet riskine göre, yeni kriterler oluşturulabilir veya mevcut modellerden alanla örtüşen göstergeler seçilebilir. Her ölçüm modelinin farklı verilere ihtiyacı vardır, bu sebeple verilere ulaşmak ve ulaşılan veriye göre yeniden göstergeleri incelemek gerekmektedir. Değerlendirme yaparken bize doğrudan ve güvenilir bilgiler vermesi dayanıklılık çalı̧̧malarında önemlidir. 


\section{$\underline{\text { Extended Abstract }}$}

\author{
Kiymet Uzun Yüksel \\ ORCID: 0000-0001-9754-7552
}

\author{
Elif L. Kutay Karaçor \\ ORCID: 0000-0001-9636-1406
}

Disaster is defined as the deterioration in the functioning of the society or in the structure of the society such as human, physical, economic and environmental factors that cause losses and effects that exceed the carrying capacity of the society (UNISDR, 2009, p.9). Removing the negative effects caused by disasters, healing and re-adapting is corrosive for both states and societies, both materially and morally. Efforts to create safe cities and urban quality of life are gaining even more importance. The concepts of disaster and resilience have begun to be used together, especially due to these disasters in recent years. Resilience to disasters provides benefits for seeing the capacity before the disaster, understanding the interventions to be made during the disaster, minimizing the damages caused by the disaster and post-disaster adaptation processes. In this context, it is necessary to investigate the resilience of cities, to take precautions and to intervene in the pre-disaster, during and post-disaster processes, in order for cities to be livable, rehabilitation and resilient environments. The aim of the study is to reveal the importance of measurement and evaluation studies within the scope of resilience in terms of urban resilience and disaster risk. For this reason, inferences were made by examining the analysis and evaluation methods that include social and spatial data in creating a model of resilience against disaster risks. In the study, the question of which methods and strategies can be applied against disasters and disaster risks of cities has been investigated.

In this study, using the keywords resilience, urban resilience, disaster risk, disaster management, measurement of resilience and evaluation of resilience, journals and books in the international database SCOPUS, national thesis center of YÖK, Dergi Park and TUBITAK project directory were scanned, secondary data analysis and content analysis methods were used. In the study, 25 models were examined, measurement methods and the differences between them were revealed. When looking at all measurement methods, especially the 
studies conducted at the city scale were examined. Among these studies, three studies with different measurement tools and methods, both social and spatial, were selected and examined. These 3 studies have been chosen because they are semi-quantitative methods with tools, indicators and scorecards applied in the city. Selected models were BRIC model, Resilient City Indicators (Arup \& Rockefeller Foundation), Disaster Resilience Scorecards For The Cities (UNISDR). These models were compared with each other according to the USA's National Institute of Standards and Technology (NIST) (2015) according to inclusivity, usability, impact assessment, techniques used and critical evaluation criteria. The comparison made according to the criteria was made to highlight the parts where the models were effective. As a result, the use case was examined in terms of applicability.

When the BRIC (Baseline resilience indicators for communities) model ( is evaluated, it is a user-friendly method that has a wide range in terms of scale and can be applied in terms of natural hazards. Evaluates the relationship of physical impact, social impact and economic impact with recovery time, partially or indirectly. Measurements can be made on existing data sets.

Resilient city index (Arup \& Rockefeller Foundation), while inclusive of scale and hazards, lack social cohesion and are less user-friendly. While evaluating the physical effect and recovery time partially and indirectly, it clearly evaluates the relationship between economic and social impact and recovery time. Checklist, interviews, fieldwork and grading are used.

UNISDR the disaster resilience scorecard for cities is inclusive of scale and hazards; but system information is missing. It is user-friendly and provides convenience in terms of public services. It evaluates the relationship of physical impact, social impact and economic impact with recovery time, partially or indirectly. Checklist and rating are used. Physical inspection, engineering analysis or seeking expert opinion is optional.

All criteria are evaluated, in terms of urban resilience, BRIC model, high inclusiveness, ease of use, average impact assessment, compatibility of existing data sets with indicators, different, reproducible, unbiased and scientifically proven. It is a more understandable method than others in terms of being a model. Information about both the place and the communities can be accessed. The Resilient City Indicators offer a slightly more complex system. For the user, more than one method may be required in the data collection and evaluation part; but clear and explanatory information is accessed. The Disaster Resilience 
Scorecard For Cities is a model that needs to be developed. It provides information about the administration and the city in general rather than the city and communities.

These models, measurement and evaluation techniques significantly guide the preparation phase in terms of guiding local governments. For this reason, the resilience of local governments against disasters can be revealed by applying the Disaster Resilience Scorecard for Cities from these three selected examples to prevent the negative consequences of disasters from local to international level and to see the current situation. In addition, communities consisting of disaster experts, non-governmental organizations and the public should be formed, and new local models should be developed together with these three models, and studies should be carried out for the processes before, during and after the disaster.

For the studies to be carried out in the urban space, urban resilience should be measured and evaluated using several different models instead of a single measurement sample. According to the place, society and disaster risk, new criteria can be created or indicators that match the area can be selected from the existing models. Each measurement model needs different data, so it is necessary to access the data and re-examine the indicators according to the data obtained. It is important in resilience studies that it gives us direct and reliable information when making an assessment.

\section{Kaynakça/References}

Adıkutlu, S. (2019). Resilience to disasters: lessons from turkish urban regeneration experiences. Yayımlanmamış yüksek lisans tezi, Ortadoğu Teknik Üniversitesi, Ankara.

AFAD. (2020). Belediyeler için afetlere dirençli kentler rehberi. İdeal Kent Yayınları, Ankara. Erişim adresi: https://belediyehizmetrehberleri.org/tr/incele1

AFAD. (2018). Türkiye'de afet yönetimi ve doğa kaynaklı afet istatistikleri. Erişim adresi: https://www.afad.gov.tr/kitaplar

Ahern, J.F. (2006). From fail-safe to safe-to-fail: sustainability and resilience in the new urban world. Landscape and Urban Planning 100(4), 341-343.

Alexander, D.E. (2013). Resilience and disaster risk reduction: an etymological journey. Nat. Hazards Earth Syst. Sci. 13, 2707-2716.

Alinovi, L., D’Errico, M., Mane, E. ve Romano, D. (2010). Livelihood strategies and household resilience to food insecurity: An empirical analysis to Kenya. European Report on Development, FAO, Rome. Erişim adresi: http://erd.eui.eu/media/BackgroundPapers/Alinovi-Romano-D'ErricoMane.pdf. 
ARUP \& Rockefeller Foundation. (2015). City resilience index. Erişim adresi: https://assets.rockefellerfoundation.org/app/uploads/20160201132303/CRIRevised-Booklet1.pdf,

Balta, M.Ö. (2013). Kentsel risklerin planlama temelinde analizi ve dirençli kent planlama yaklaşım. Yayımlanmamış doktora tezi, Gazi Üniversitesi, Ankara.

Berry, C., Ryan-Collins, J. ve Greenham, T. (2015). Financial system resilience index: Building a strong financial system. New Economics Foundation, London. Erişim adresi: http://b.3cdn.net/nefoundation/70470851bfaddff2a2_xem6ix4qg.pdf.

Campanella, T. J. (2006). Urban resilience and the recovery of New Orleans. Journal of the American Planning Association, 72(2), 141-146. doi: 10.1080/01944360608976734

CARRI. (2013) Building resilience in America's communities: observations and implications of the CRS pilots. Community \& Regional Resilience (CARRI) report. Erişim adresi: http://www.resilientus.org/wpcontent/uploads/2015/04/CRS-Final-Report.pdf

Cimellaro, G. P. (2016). Urban resilience for emergency response and recovery: Fundamental concepts and applications. Switzerland: Springer.

Cohen, O., Leykin, D., Lahad, M., Goldberg, A., \& Aharonson-Daniel, L. (2013). The conjoint community resiliency assessment measure as a baseline for profiling and predicting community resilience for emergencies. Technological Forecasting and Social Change, 80(9), 1732-1741.

Cox, R. S., \& Hamlen, M. (2015). Community disaster resilience and the rural resilience index. American Behavioral Scientist, 59(2), 220-237.

Cutter, S. L. (2016). The landscape of disaster resilience indicators in the USA. Natural Hazards, 80(2), 741-758.

Cutter, S. L., Ash, K. D., \& Emrich, C. T. (2014). The geographies of community disaster resilience. Global Environmental Change, 29, 65-77.

Cutter, S. L., Burton, C. G., \& Emrich, C. T. (2010). Disaster resilience indicators for benchmarking baseline conditions. Journal Of Homeland Security And Emergency Management, 7(1).

Cutter, S. L., Barnes, L., Berry, M., Burton, C., Evans, E., Tate, E., \& Webb, J. (2008). A place-based model for understanding community resilience to natural disasters. Global Environmental Change, 18(4), 598-606.

Erdinç, F. (2018). Afetlere karşı kentlerin dirençlilĭği: İstanbul örneği. Yayımlanmamış yüksek lisans tezi, Gazi Üniversitesi, Ankara.

Ernstson, H., Van der Leeuw, S. E., Redman, C. L., Meffert, D. J., Davis, G., Alfsen, C., \& Elmqvist, T. (2010). Urban transitions: on urban resilience and humandominated ecosystems. Ambio, 39(8), 531-545.

Figueiredo, L., Honiden T. \& Schumann A. (2018). Indicators for resilient cities. Erişim adresi: $\quad$ https://www.oecd-ilibrary.org/docserver/6f1f6065en.pdf?expires $=1637070002 \&$ id=id\&accname=guest\&checsum=7E40E88BFE2249BA3E6D50D15C309328. 
Fisher, R.E., Bassett, G.W., Buehring, W.A., Collins, M.J., Dickinson, D.C., Eaton, L.K., Haffenden, R.A., Hussar, N.E., Klett, M.S., Lawlor, M.A., Miller, D.J., Petit, F.D., Peyton, S.M., Wallace, K.E., Whitfield, R.G. \& Peerenboom, J.P. (2010). Constructing a resilience index for the enhanced critical infrastructure program. Erişim adresi: http://www.ipd.anl.gov/anlpubs/2010/09/67823.pdf.

Hillier, D. Castillo, \& G. (2013). No accident: resilience and the inequality of risk. Erişim adresi: $\quad$ https://www.oxfam.org/en/research/no-accident-resilience-andinequality-risk

Hosseini, S., Barker, K. \& Ramirez-Marquez, J. E. (2016). A review of definitions and measures of system resilience. Reliability Engineering and System Safety, 145, 4761. doi: 10.1016/j.ress.2015.08.006.

Hughes, K., \& Bushell, H. (2013). A multidimensional approach for measuring resilience. Erişim adresi: http://policy-practice.oxfam.org.uk/publications/amultidimensional-approach-to-measuringresilience-302641

ICLEI. (2015). Local governments for sustainability, climate resilient cities. Erişim adresi: http://www.iclei.org/ouractivities/our-agendas/resilient-city.html

Godshalk, D.R. (2003). Urban hazard mitigation: creating resilient cities. Natural Hazard Review, 4(3), 136-143.

Harrison, C.G. \& Williams, P.R. (2016). A systems approach to natural disaster resilience. Simulation Modelling Practice and Theory, 65, 11-31. http://dx.doi.org/10.1016/j.simpat. 2016.02.008.

Holling, C.S. (1973). Resilience and stability of ecological systems. Annual Review of Ecology and Systematics, 4, 1-23.

Karahan Özkur, A. (2018). Dirençli Kentler Bă̆lammıda Karaman Kentinin Değerlendirilmesi. Yayımlanmamış yüksek lisans tezi, Ankara Üniversitesi, Ankara.

Meerow, S., Newell, J. P., \& Stults, M. (2016). Defining urban resilience: a review. Landscape and Urban Planning, 147, 38-49.

NIST. (2015). Critical Assessment of Existing Methodologies for Measuring or Representing Community Resilience of Social and Physical Systems Erişim adresi: https://nvlpubs.nist.gov/nistpubs/gcr/2015/NIST.GCR.15-1010.pdf

Oxford Metrica. (2015). 2015 FM Global Resilience Index, Oxford. Erişim adresi: https://www.fmglobal.com/assets/pdf/Resilience_Methodology.pdf

Peacock, W.G., Brody, S.D., Seitz, W.A., Merrell, W.J., Vedlitz, A., Zahran, S., Harriss, R.C., Stickney, R.R. (2010). Advancing the resilience of coastal localities: developing, implementing and sustaining the use of coastal resilience indicators: A final report. Erişim adresi: http://hrrc.arch.tamu.edu/media/cms_page_media/558/10-02R.pdf

Pendall, R., Foster, K. A., \& Cowell, M. (2010). Resilience and regions: building understanding of the metaphor. Cambridge Journal of Regions, Economy and Society, 3(1), 71-84.

Petit, F. D. P., Bassett, G. W., Black, R., Buehring, W. A., Collins, M. J., Dickinson, D. C., ... \& Phillips, J. A. (2013). Resilience measurement index: An indicator of critical 
infrastructure resilience. Erişim adresi: https://publications.anl.gov/anlpubs/2013/07/76797.pdf

Pfefferbaum, R. L., Pfefferbaum, B., Van Horn, R. L., Klomp, R. W., Norris, F. H., \& Reissman, D. B. (2013). The communities advancing resilience toolkit (CART): An intervention to build community resilience to disasters. Journal Of Public Health Management And Practice, 19(3), 250-258.

Pickett, S. T., Cadenasso, M. L., \& Grove, J. M. (2004). Resilient cities: meaning, models, and metaphor for integrating the ecological, socio-economic, and planning realms. Landscape and Urban Planning, 69(4), 369-384.

Renschler, C. S., Frazier, A. E., Arendt, L. A., Cimellaro, G. P., Reinhorn, A. M., \& Bruneau, M. (2010, Ekim 8). A framework for defining and measuring resilience at the community scale: The PEOPLES resilience framework. Erişim adresi: https://www.eng.buffalo.edu/mceer-reports/10/10-0006.pdf.

SCOPUS. (2020). Dayanıklılık (resilience), afet (disaster), afet yönetimi (disaster management) değerlendirme (assessment), ölçme (measurement) kelimeleri kullanılarak yapılan tarama. 1 Eylül 2020 tarihinde https://www.scopus.com adresinden erişildi.

Sempier, T. T., Swann, D. L., Emmer, R., Sempier, S. H., \& Schneider, M. (2010). Coastal community resilience index: A community self-assessment. MississippiAlabama Sea Grant Consortium. Erişim adresi: http://www.southernclimate.org/documents/resources/Coastal_Resilience_Inde x_Sea_Grant.pdf

Sherrieb, K., Norris, F. H., \& Galea, S. (2010). Measuring capacities for community resilience. Social Indicators Research, 99(2), 227-247.

Şirin Dinçer, Ş. E. (2016). Dayanıkl kentler için kentsel tasarım ilkeleri. Yayımlanmamış yüksek lisans tezi, Mimar Sinan Güzel Sanatlar Üniversitesi, İstanbul.

Timmerman, P. (1981). Vulnerability resilience and collapse of society: A Review of Models and Possible Climatic Applications. Institute for Environmental Studies, University of Toronto. Toronto, Canada.

TNC. (2015). Coastal resilience tool. Erişim adresi: http://Coastalresilience.org/tool.

Twigg, J. (2009). Characteristics of a disaster-resilient community: A guidance note, version $2 . \quad$ Erişim adresi: https://discovery.ucl.ac.uk/id/eprint/1346086/1/1346086.pdf

Ulusal Tez Merkezi. (2020). Dayanıklı (resilient), dayanıklılık (resilience), afet (disaster), afet yönetimi (disaster management) değerlendirme (assessment), ölçme (measurement) kelimeleri kullanılarak yapılan tarama. 1 Aralık 2020 tarihinde https://tez.yok.gov.tr/UlusalTezMerkezi/tezSorguSonucYeni.jsp adresinden erişildi.

UNDP. (2014) Understanding community resilience: findings from community-based resilience analysis (CoBRA) assessments. Erişim adresi: http://www.disasterriskreduction.net/fileadmin/user_upload/drought/docs/Co BRA\%20Assessments\%20Report.pdf 
UNISDR. (2019). Global assessment report on disaster risk reduction Erişim adresi: https://gar.undrr.org/report-2019

UNISDR. (2017). Disaster resiliece scorecards for cities. Erişim adresi: https://www.unisdr.org/campaign/resilientcities/assets/toolkit/Scorecard/UND RR_Disaster\%20resilience\%20\%20scorecard\%20for\%20cities_Preliminary_Engl ish.pdf

UNISDR. (2016, Mart 3). Open-ended intergovernmental expert working group on indicators and terminology relating to disaster risk reduction: report of the second session (informal and formal). Erişim adresi: https://www.preventionweb.net/files/47136_reportsecondsessionoiewg.pdf

UNISDR. (2013) Making cities resilient: summary for policymakers. Erişim adresi: http://www.preventionweb.net/files/33059_33059finalprinterversionexecutives u.pdf

UNISDR. (2009). Terminology on disaster risk reduction. Erişim adresi: https://www.unisdr.org/files/7817_UNISDRTerminologyEnglish.pdf

USIAD. (2016). Resilience at USIAD 2016 progress report. Erişim adresi: https://www.usaid.gov/sites/default/files/documents/1867/082816_Resilience_Fi nalB.PDF

USAID. (2013) The resilience agenda: measuring resilience in USAID Erişim adresi: https://www.usaid.gov/sites/default/files/documents/1866/Technical\%20Note_ Measuring\%20Resilience\%20in\%20USAID_June\%202013.pdf

USEPA. (2015). Climate resilience evaluation \& awareness tool (CREAT). Erişim adresi: http://water.epa.gov/infrastructure/watersecurity/climate/creat.cfm

White, R. K., Edwards, W. C., Farrar, A., \& Plodinec, M. J. (2015). A practical approach to building resilience in America's communities. American Behavioral Scientist, 59(2), 200-219.

World Bank. (2015). Atlas of social protection: indicators of resilience and equity. Erişim adresi: $\quad$ https://practicalaction.org/docs/ia1/community-characteristics-enlowres.pdf

Yaman Galantini, Z.E. (2018). Urban resilience as a policy paradigm for sustainable urban planning and urban development: the case of istanbul (Sürdürülebilir kent planlama ve kentsel kalkınma için bir politika paradigması olarak kentsel dayanıkllık: İstanbul örneği). Yayımlanmamış doktora tezi, İstanbul Teknik Üniversitesi, İstanbul. 